\title{
Impact of Goods Quality and Advertising on Buying Decision of Gembira Bread Brand
}

\author{
Rakhmawati Purba \\ STIE Bina Karya Tebing Tinggi, Indonesia \\ Tel: 62-812-651-6214 E-mail: rahmapurba2009@gmail.com,
}

Aisyah Siregar

STIE Bina Karya Tebing Tinggi, Indonesia

Rusmewahni

STIE Bina Karya Tebing Tinggi, Indonesia

\begin{abstract}
Received: August 21, 2020 Accepted: September 20, 2020 Published: October 19, 2020
doi:10.5296/ber.v10i4.17558～URL: https://doi.org/10.5296/ber.v10i4.17558
\end{abstract}

\begin{abstract}
The purpose of this study was to determine the impact of the quality of goods and advertisements on the decision to buy Gembira bread brand. The independent variable of this study consists of the quality of goods and advertisements, while the dependent variable is the buying decision. This research is quantitative descriptive. The research was conducted on the community in the Padang Hilir District, Tebing Tinggi City. The data used are primary data obtained through questionnaire answers from 50 respondents. Data were analyzed using multiple linear regression analysis method. The results showed that the quality of the goods had a significant impact on buying decisions. Likewise, advertising has a significant impact on Buying Decision. For further researchers, it is hoped that they can examine other factors that are not revealed in this study.
\end{abstract}

Keywords: Quality of goods, Advertising, Buying decision

\section{Preliminary}

In the current period of competition, the level of competition in the business world in Indonesia is very tight, because every company is always trying to increase market share and reach new customers. Companies must be able to determine the right marketing strategy so 
that their business can survive and win the competition. This is also the case with snack companies, such as Gembira bread.

Consumer behavior is very decisive in buying decisions, which stage starts from the identification of the problem, namely in the form of pressure that generates action to meet and satisfy needs. According to Kotler and Keller (2016:151), "buying decisions are a stage of consumer evaluation in forming preferences for brands in a collection of various behaviors". Consumers may also form the intention to buy the product they most like.

Companies that use quality as a strategic tool will have a competitive advantage over their competitors in controlling the market. The quality of goods according to Herlambang (2016) is "the ability of a product that carries out its functions, including reliability, durability, ease of operation and repair, as well as other valuable attributes"

Quality products will generate consumer confidence to keep making purchases. The quality of the goods is closely related to the buying decision because if the product chosen by the consumer does not meet the standard or good quality, it is likely that the consumer will choose another alternative or prefer another product because the quality or quality provided does not meet the standards desired by the consumer.

Efforts to introduce products to the market are through advertising strategies. Klarisa (2019) states that advertising is a determining factor for the success of a marketing program or marketing strategy. No matter how good a product that is marketed if consumers never hear and do not know whether the product is useful for them then they will not buy it.

Advertising is a one-way flow of information or persuasion designed to direct a person or organization to the act of creating exchange in marketing. It can be seen that the advertising strategy is a planned activity with the intention of persuading, stimulating consumers to buy company products so that the goal of increasing sales is expected to be achieved (Mongi et. Al., 2017).

Based on the monitoring carried out on several things that make buying decisions by consumers in buying bread with the Gembira bread brand, including the consumers seeing whether the product is of good quality and whether it is good for consumption because of the large number of breads that use chemicals that are harmful to the body. And the fact is that the bread is very good quality, very delicious, soft and safe to eat, because the bread is made directly in the factory and sold directly by the seller of the factory.

This bread is sold in supermarkets, stalls and this product really maintains its quality. In terms of timeframe, the bread sold is not long because the company wants consumers to get fresh or delicious bread for consumption.

After some time researched in the field directly by asking opinions from consumers as well as sellers from the factory, it is known that this bread is in great demand and every consumer who knows about the quality and taste of this bread the consumers return to buy again and again.

Meanwhile, with good advertising, it is hoped that communication will occur between 
producers and consumers. With this communication, it is hoped that it can acquire new customers and retain old consumers.

From the above phenomenon, it shows that the quality of goods and advertisements play a role in modern lifestyle, so that the desire to buy quality products and advertisements also has an impact on one's consumption patterns. These considerations are based on many aspects, both rational and emotional. Likewise with previous research which states that the quality of an item greatly influences the purchase decision, while advertising is not so significant in the purchase decision.

Rationally, consumers believe that a good product can guarantee good quality as well. Emotionally, these products are considered capable of maintaining or increasing prestige and good relations with users and stimulating consumers to buy products which are a marketing strategy.

Based on the explanation above, the researcher is interested in trying to find out the suitability between theory and reality in the field, whether the quality of goods and advertisements has an impact on the decision to buy Roti Gembira products in Padang Hilir Subdistrict, Tebing Tinggi City, thus making a study entitled "Quality Impacts. goods and advertisement on the decision to buy Gembira bread brand in Tebing Tinggi "

\subsection{Formulation of the Problem}

Based on the aforementioned background, problem formulations can be made, namely (1) Does the quality of the goods have an impact on the decision to buy Gembira bread products in the Padang Hilir Subdistrict Community, Tebing Tinggi City? (2) Does the advertisement have an impact on the decision to buy Gembira bread products for the community in Padang Hilir District, Tebing Tinggi City? and (3) Does the quality of goods, and advertisements simultaneously have an impact on the decision to buy Gembira bread products for the community in Padang Hilir District, Tebing Tinggi City?

\subsection{Research Purposes}

The objectives of this study are (1) to determine how the impact of the quality of goods on the decision to buy Gembira bread products, (2) to find out how the impact of advertising on the decision to buy Gembira bread products, and (3) to find out how the impact of the quality of goods and advertisements on buying decision Gembira bread products.

\section{Theoretical Basis}

\subsection{Buying Decision}

Setiadi (2018) states that the essence of consumer decision making is an integration process that combines knowledge to evaluate two or more alternative behaviors, and choose one of them.

The specific buying process consists of the following sequence of events: problem recognition, information seeking, alternative evaluation, buying decisions, and post-buying behavior (Setiadi, 2018). Buying decisions cannot be separated from consumer behavior. 
The decision to buy is a real process of buying or not (Handoko and Swastha, 2015). According to Kotler and Keller (2016), a buying decision is that consumers form an intention to buy the most preferred brand. The task of producer is to understand what the consumer needs or wants to fulfill all their wants or needs.

According to Kotler (2019) a specific buying process consists of the following sequence of events:

1. Introduction of the needs of the early stages of a buying decision. Consumers recognize the problem of the need for the product to be purchased, consumers feel the difference between the real situation and the desired state.

2. Information search for the stage of buying decisions that can stimulate consumers to seek more information. The consumer may be simply increasing attention or may be actively seeking information.

3. Evaluation of alternative processes carried out by consumers to use the information obtained to evaluate existing alternatives to the process of selecting products to be purchased.

4. Buying decisions consumers plan to buy a product and then buy certain products to meet their needs.

5. Post-buying behavior is a follow-up action after buying based on whether or not they are satisfied with the product used.

\subsection{Quality of Goods}

One of the main values that customers expect from producers is the highest quality of goods and services. Quality of goods is how to describe the product that can provide something that can satisfy consumers.

The opinion put forward by Kotler and Keller (2016:240) states that the quality of goods is the ability of a product to carry out its function, including durability, reliability, accuracy, ease of operation and repair as well as other valuable attributes. The quality of goods is an important thing that must be endeavored by every company if they want the product to be able to compete in the market to satisfy the needs and desires of consumers.

Meanwhile, according to Kotler and Armstrong (2016:230) defines: Product quality: The characteristics of a product or service that bear on its ability to satisfy stated or implied customer needs. This opinion states that the quality of goods is a characteristic of a product or service that supports its ability to satisfy customer needs.

From some of the definitions above, it can be concluded that the quality of goods is the ability of a product to meet customer desires. The desires of these customers include product durability, product reliability, ease of use and other valuable attributes. This is in line with the formulation of the problem which wants to know whether the quality of goods has an impact on purchasing decisions

\subsection{Advertisement}

Advertising is the most persuasive sales message directed to the most potential buyers of a 
particular product or service at the lowest cost.

Advertising is one of the variables in the marketing mix which is very important for companies to implement in marketing their products or services. Sometimes the term advertising is used synonymously with the term sales even though it means advertising.

The definition of advertising according to Kotler and Armstrong (2016:76), "Promotion means activities that communicate the merits of the product and persuade target customers to buy it", meaning that advertising is an activity that communicates the benefits of a product and persuades target consumers to buy the product.

One thing that supports sales success is advertising. Advertising is used by companies to introduce products to the wider community so that awareness of a company's product can increase. Advertising is also used by companies to inform the benefits of a product.

According to Kotler and Armstrong (2016:432), the advertising mix consists of 5 (five) advertising tools, namely:

1. Advertising, which is all forms of presentation and non-personal advertising paid for by the sponsor to present ideas, goods or services. Advertising is considered as image management that aims to create and maintain creativity and meaning in the minds of consumers. The forms of advertising used include broadcast, print, internet, outdoor, and other forms.

2. Sales promotion (sales advertising), namely short-term incentives to encourage buying or selling of a product or service. The forms of advertising used include discounts, coupons, displays, demonstrations, contests, sweepstakes, and events

3. Personal selling (personal sales), namely personal presentations by salespeople with the aim of generating sales and building relationships with consumers. The forms of advertising used include presentations, trade shows, and incentive programs.

4. Public relations, which is to build good relationships with various public companies in order to obtain favorable publicity, build a good corporate image, and handle or correct rumors, stories, and events that are not profitable. The forms of advertising used include press releases, sponsorships, special events, and web pages.

5. Direct marketing (direct sales), namely direct relationships with target consumers with the aim of obtaining immediate responses and fostering lasting relationships with consumers. The forms of advertising used include catalogs, telephone marketing, kiosks, internet, mobile marketing, and others.

This is in line with the formulation of the problem that wants to know the extent to which advertising has an impact on purchasing decisions

\subsection{Conceptual Framework}

The purpose of this study was to examine the impact of the quality of goods and advertisements on the decision to buy Gembira bread brand. The buying decision is the dependent variable, while the quality of goods and advertisements are the independent variables. 
The research conceptual framework can be described as follows:

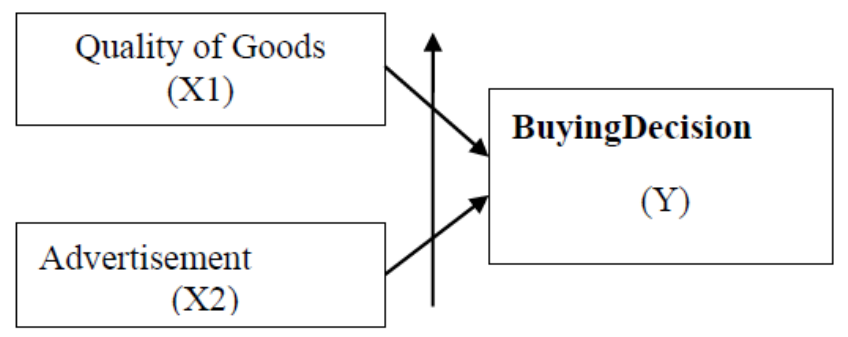

Figure 1. Conceptual Framework

\subsection{Hypothesis}

Based on the background, problem formulation, and theoretical studies, the following research hypotheses can be formulated: (1) The quality of the goods has an impact on the decision to buy Gembira bread brand, (2) Ads have an impact on the decision to buy Gembira bread brand, and (3) the quality of the goods and advertising simultaneously impacts Gembira bread brand buying decisions.

\section{Research Methodology}

\subsection{Population and Sample}

Population is a generalization area consisting of objects / subjects that have certain qualities or characteristics that have been determined by researchers to study and then draw conclusions (Sugiyono, 2017). The research population is the people of Padang Hilir Subdistrict, Tebing Tinggi City, who have bought Gembira products, which are estimated to be 50 people with consideration of research time and cost. A sample that is too large brings its own problems for researchers, especially with regard to ethical issues and research resources, which will take a lot of time and money.

In this study, the sampling technique used is probability sampling by means of the census method, where the total population is sampled. Because the population is below 100 people, the total population is used as a research sample, which is 50 samples

\subsection{Types and Sources of Data}

This research is quantitative descriptive. The type of data in this study is quantitative data sourced from primary data, namely data obtained through direct research into the object of research with a saturated sample of 50 people either by questionnaire or direct interview which researchers still have to process.

\subsection{Data Analysis Technique}

This study analyzed data with multiple linear regression methods using the help of statistical software IBM SPSS Statistics 20 . The models tested were: $\mathrm{Y}=\alpha+\beta 1 \mathrm{X} 1+\beta 2 \mathrm{X} 2+\mathrm{e}$ 


\section{1) Macrothink}

Where:

$\mathrm{Y}=$ Purchase decision

X1 = Quality of goods

$\mathrm{X} 2=$ Advertisement

$\alpha=$ Constant

$\beta 1,2=$ Regression coefficient

$\mathrm{e}=$ standard error

\subsection{Classic Assumption Test}

The classic assumption test in this study includes the normality test, multicollinearity test, and heteroscedasticity test. The normality test uses the Kolmogorov-Smirnov test provided that the data is normally distributed if the Asymp value. Sig. (2-tailed) is greater than 0.05. To test the multicollinearity problem, this study uses the VIF (Variance Inflation Factor) number as a benchmark for whether there is a multicollinearity problem in the model. The model is said to be free from multicollinearity problems if the VIF value is $<10$. This study detects heteroscedasticity by looking at the graph plot between the predicted value of the dependent variable (ZPRED) and its residual (SRESID).

\section{Results and Discussion}

\subsection{Classic Assumption Test}

Normality test

The results of the normality test are shown in Table 1 below:

Table 1. Normality Test Results

\begin{tabular}{|c|c|c|c|}
\hline \multicolumn{4}{|c|}{ One-Sample Kolmogorov-Smirnov Test } \\
\hline & & & Unstandardized Residual \\
\hline \multicolumn{3}{|l|}{$\mathrm{N}$} & 50 \\
\hline \multirow[t]{2}{*}{ Normal Parameters ${ }^{\mathrm{a}, \mathrm{b}}$} & \multicolumn{2}{|l|}{ Mean } & $0 \mathrm{E}-7$ \\
\hline & \multicolumn{2}{|l|}{ Std. Deviation } & 1,01737706 \\
\hline \multirow[t]{3}{*}{ Most Extreme Differences } & \multicolumn{2}{|l|}{ Absolute } & 075 \\
\hline & \multicolumn{2}{|l|}{ Positive } &, 075 \\
\hline & \multicolumn{2}{|l|}{ Negative } &,- 074 \\
\hline \multicolumn{3}{|l|}{ Kolmogorov-Smirnov Z } &, 527 \\
\hline \multicolumn{3}{|l|}{ Asymp. Sig. (2-tailed) } & ,944 \\
\hline \multirow[t]{3}{*}{ Monte Carlo Sig. (2-tailed) } & \multicolumn{2}{|l|}{ Sig. } & $925^{\mathrm{c}}$ \\
\hline & \multirow{2}{*}{$\begin{array}{l}\text { 99\% Confidence } \\
\text { Interval }\end{array}$} & Lower Bound & ,918 \\
\hline & & Upper Bound & ,932 \\
\hline
\end{tabular}




\section{Macrothink}

Based on Table 1, it can be seen that the significance value of Asymp.Sig 2-tailed all variables is 0.918 . If the significance is more than 0.05 , then the residual value is normal, so it can be concluded that all variables are normally distributed.

\subsection{Multicollinearity Test}

The multicollinearity test aims to determine whether in the regression model there is a correlation between the independent variables. The multicollinearity test results are summarized in Table 2 below:

Table 2. Multicollinearity Test Results

\begin{tabular}{|l|l|l|}
\hline Variable & VIF & Conclusion \\
\hline X1 & 1.172 & Multicollinearity Free \\
\hline X2 & 1.172 & Multicollinearity Free \\
\hline
\end{tabular}

From Table 2 above, it is known that the VIF value is $<10$. This indicates that the model is free from multicollinearity problems.

\subsection{Heteroscedasticity Test}

The heteroscedasticity test aims to test whether in the regression model there is an inequality of variance from the residuals of one observation to another. The results of the heteroscedasticity test are shown in Figure 2 below:

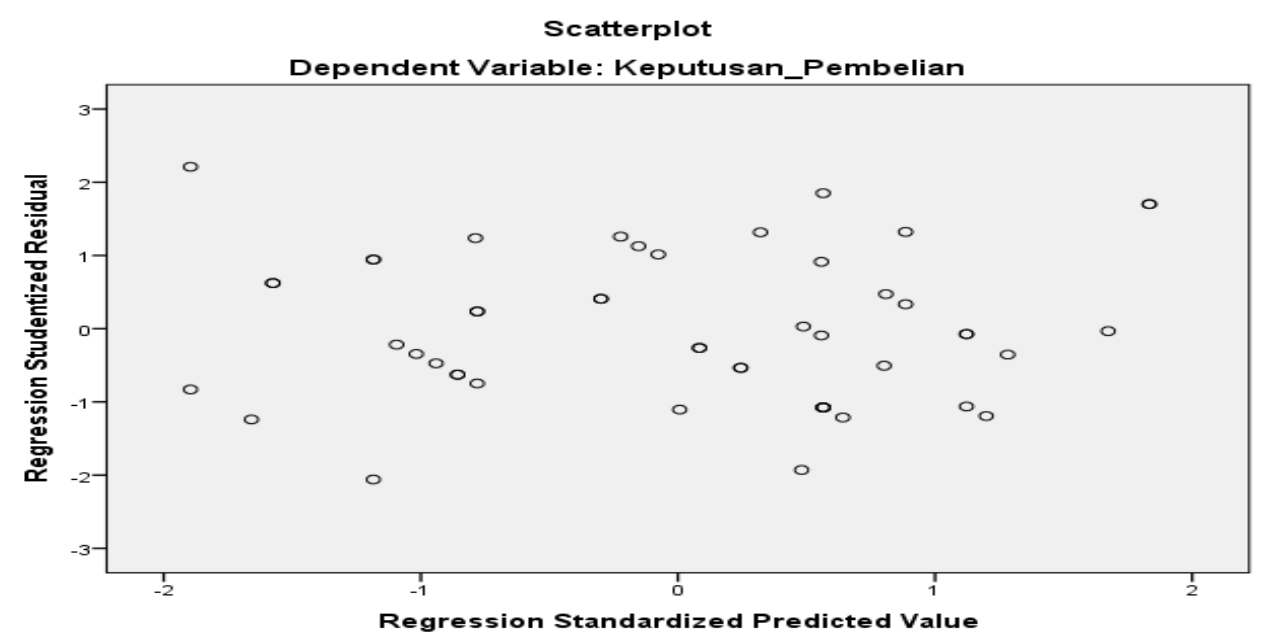

Figure 2. Scatterplot graph

Based on Figure 2, it can be seen if the data pattern is perfectly spread, some are above the zero point and some are spread below the zero point. Because of this, it can be concluded that there are no symptoms of heteroscedasticity in the regression model. 


\subsection{Hypothesis Test}

Test the coefficient of determination (Adjusted R2)

The results of the coefficient of determination test can be seen in Table 3 below:

Table 3. The results of the determination coefficient test

\begin{tabular}{|c|c|c|c|c|c|c|c|c|c|}
\hline \multicolumn{10}{|c|}{ Model Summary ${ }^{b}$} \\
\hline \multirow[t]{2}{*}{ Model } & \multirow[t]{2}{*}{$\mathrm{R}$} & \multirow[t]{2}{*}{ R Square } & \multirow{2}{*}{$\begin{array}{l}\text { Adjusted R } \\
\text { Square }\end{array}$} & \multirow{2}{*}{$\begin{array}{l}\text { Std. Error of } \\
\text { the Estimate }\end{array}$} & \multicolumn{5}{|c|}{ Change Statistics } \\
\hline & & & & & $\begin{array}{l}\text { R Square } \\
\text { Change }\end{array}$ & $\begin{array}{l}\text { F } \\
\text { Change }\end{array}$ & df1 & $\mathrm{df2}$ & $\begin{array}{l}\text { Sig. } \\
\text { F Change }\end{array}$ \\
\hline 1 &, $863^{\mathrm{a}}$ & ,745 &, 735 & 1,03880 & ,745 & 68,836 & 2 & 47 & ,000 \\
\hline
\end{tabular}

Based on Table 3, it can be seen that the adjusted $\mathrm{R}$ square value is 0.735 or $73.5 \%$. This shows that the quality variable (X1) and advertising variable (X2) can explain the purchase decision variable (Y) for $73.5 \%$, the remaining $26.5 \%$ (100\% - 73.5\%) is explained by other variables in beyond this research model.

\subsection{Statistical Test F}

The results of the F statistical test can be seen in Table 4 below:

Table 4. Statistical Test Results F

\begin{tabular}{|c|c|c|c|c|c|c|}
\hline \multicolumn{7}{|c|}{ ANOVA $^{\mathrm{a}}$} \\
\hline \multicolumn{2}{|c|}{ Model } & Sum of Squares & $\mathrm{df}$ & Mean Square & $\mathrm{F}$ & Sig. \\
\hline \multirow[t]{3}{*}{1} & Regression & 148,562 & 2 & 74,281 & 68,836 &, $000^{\mathrm{b}}$ \\
\hline & Residual & 50,718 & 47 & 1,079 & & \\
\hline & Total & 199,280 & 49 & & & \\
\hline
\end{tabular}

a. Dependent Variable: Y

b. Predictors: (Constant), X2, X1

From Table 4, it is found that the value of Fcount is 68.836 with $\alpha=5 \%$, df of the numerator: 2, df of the denominator: 47, F-table: 3.195. From this description, it can be seen that F count (68.836) $>\mathrm{F}$ table (3.195), and a significance value of $0.000 \mathrm{~b}<0.05$, it can be concluded that the third hypothesis is accepted, meaning that the quality variable (X1) and the advertising variable (X2) have a joint impact - same (simultaneously) on the Purchasing Decision Variable (Y).

\subsection{T Test}

The $\mathrm{t}$ test results can be seen in Table 5 below: 
Table 5. T Test

\begin{tabular}{|l|l|l|l|l|l|l|}
\hline \multicolumn{2}{|l|}{ Coefficients $^{\mathrm{a}}$ Model } & Unstandardized Coefficients & Standardized Coefficients & $\mathrm{t}$ & Sig. \\
\cline { 3 - 8 } \multicolumn{2}{|l|}{} & B & Std. Error & Beta & & \\
\hline \multirow{2}{*}{1} & (Constant) & 1,726 & 1,502 & & 1,149 &, 256 \\
\cline { 2 - 7 } & $\mathrm{X} 1$ &, 413 &, 049 &,- 184 & 8,497 &, 000 \\
\cline { 2 - 7 } & $\mathrm{X} 2$ &, 279 &, 066 &, 439 & 4,220 &, 000 \\
\hline
\end{tabular}

Regression equation: $\mathrm{Y}=1.726+0.413 \mathrm{X} 1+0.279 \mathrm{X} 2$

From Table 5, it can be seen that the $\mathrm{t}$ count value is 8.497 . With $\alpha=5 \%, \mathrm{t}$ table $(5 \%$; $\mathrm{n}-\mathrm{k}=$ $50-3=47$ ) obtained $t$ table value of 2.012. From this description, it can be seen that $t$ count (8.497) > t table (2.012), as well as the significance value of $0.000<0.05$, it can be concluded that the first hypothesis is accepted, meaning that the variable quality of goods (X1) has an impact on the Purchasing Decision Variable (Y)

Table 5 also shows the $\mathrm{t}$ count value of 4,220 . With $\alpha=5 \%, \mathrm{t}$ table $(5 \%$; $\mathrm{n}-\mathrm{k}=50-3=47)$ obtained t table value of 2.012. From this description it can be seen that $t$ count $(4,220)>$ t table $(2,012)$, and a significance value of $0,000<0.05$, it can be concluded that the second hypothesis is accepted, meaning that Advertising Variable (X2) has an impact on the Purchasing Decision Variable (Y).

\section{Conclusions and Recommendations}

\subsection{Conclusion}

Based on the results of the analysis, several conclusions can be drawn as follows:

1. The quality of the goods has a significant impact on buying decisions.

2. Advertising has a significant impact on buying decisions.

3. The quality of goods and advertisements have a collective impact on consumer buying decisions.

\subsection{Recommendation}

Based on some of the conclusions above, the suggestions that researchers can provide include the following:

1. It is hoped that Gembira Bread Entrepreneurs will always maintain the quality of their products and continue to improve the quality of Gembira Bread for the better in the future.

2. Gembira Bread Entrepreneurs must pay more attention to all aspects that have an impact on buying decisions, so that sales stability is maintained and continues to increase.

3. For further researchers, it is hoped that the research will be able to expand on other factors 


\section{Macrothink}

Business and Economic Research ISSN 2162-4860 2020, Vol. 10, No. 4

apart from the factors that have been studied so that the research can be broader in scope.

\section{References}

Handoko \& Swastha. (2015). Marketing Management. Edition 3: Publisher: Erlangga, Jakarta.

Herlambang, S. (2016). Basic Marketing (Marketing Basics): Easy Ways to Understand Marketing Science. Yogyakarta: Tri-Al-Bros Publishing.

Kotler \& Keller. (2016). Marketing Management. Edition 13. Volume 1. Erlangga, Jakarta.

Kotler, Philip, \& Keller. (2016). Marketing Analysis. Edition 13. Volume 1. Linguist, Bob Sabran. Erlangga, Jakarta.

Klarisa, N. (2019). Impact of Advertising Mix on Decision to Buy Services at Employee Speaking Educational Institutions. Balikpapan.

Kotler, P. (2019). Principles of Marketing. Jakarta: Erlangga.

Kotler, P., \& Kevin, L. K. (2016). Marketing Management. Jakarta: PT Gramedia Group Index.

Kotler, Philip, \& Keller. (2017). Consumer Behavior, Implications for Marketing Strategy, first edition, first printing. Publisher: PT Graha Ilmu, Jakarta.

Mongi, L., Mananeke, L., \& Repi, A. (2013). Quality of goods, Advertising Strategy and Price Impact on Decision to Buy Telkomsel Sympathy Card in Manado City. Emba Journal, 1(4), 2336-2346.

Sugiyono. (2017). Business Research Methods. Bandung: CV. Alfabeta.

\section{Copyright Disclaimer}

Copyright for this article is retained by the author(s), with first publication rights granted to the journal.

This is an open-access article distributed under the terms and conditions of the Creative Commons Attribution license (http://creativecommons.org/licenses/by/4.0/). 